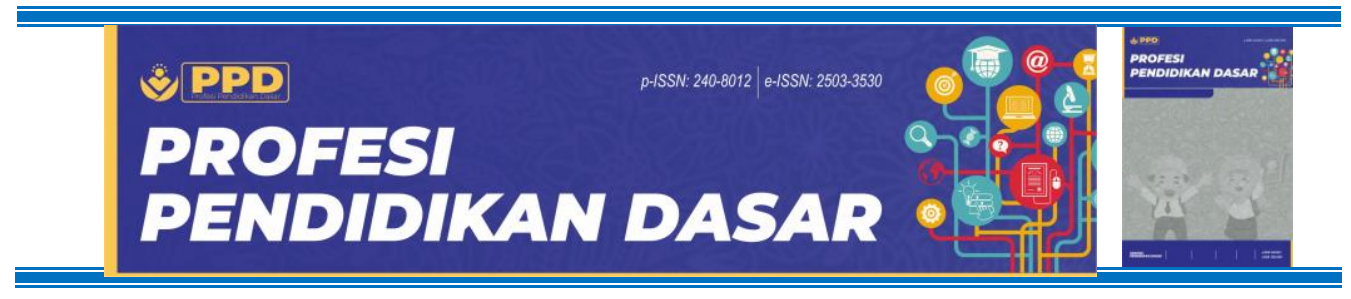

\title{
Apakah Learning Start with a Question Efektif Digunakan dalam Microteaching?: Eksperimen pada Calon Guru Sekolah Dasar
}

\author{
Nina Gantina ${ }^{1 *}$ \& Ahmad Khoiri ${ }^{2}$ \\ ${ }^{1}$ Sekolah Tinggi Keguguran dan IImu Pendidikan Banten, Kota Serang, Indonesia \\ ${ }^{2}$ Universitas Sains Al Qur'an, Wonosobo, Indonesia \\ *Email \& Phone: ninagantina@ymail.com \& +6282122227371
}

Submitted: $2020-10-13$

DOI: $10.23917 /$ ppd.v7i2.12311

Accepted: $2020-12-03$

Published: $2020-12-20$

\begin{tabular}{|c|c|}
\hline Keywords: & Abstract \\
\hline $\begin{array}{l}\text { Elementary School } \\
\text { Teacher } \\
\text { Candidates, } \\
\text { LSQ Learning, } \\
\text { Microteaching }\end{array}$ & $\begin{array}{l}\text { Prospective Elementary School Teachers have difficulty in understanding the } \\
\text { science concepts. Beside, they are generally low in curiosity, passive in } \\
\text { discussion, and lack of collaboration on microteaching activities. This study } \\
\text { aims to: (1) Reveal how to apply the experimental-based LSQ learning model } \\
\text { on microteaching activities for elementary school teacher candidates; (2) } \\
\text { Examine the increase in curiosity and understanding the concept of science. } \\
\text { The method used is a Quasi-experiment method with purposive sampling } \\
\text { technique. The sample are } 31 \text { elementary school teacher candidates from } \\
\text { Universitas Sains Al Quran, Wonosobo, Indonesia. The data about } \\
\text { understanding the concept was collected through a test with } 30 \text { questions. } \\
\text { The data about curiosity was collected by questionnaires and observation } \\
\text { sheets. The results showed that there is an increase in the understanding of } \\
\text { the concept based on the gain test of } 0.3 \text {. Furthermore, based on the t-test of } \\
4.01 \text { and t-table of } 1.99 \text { (tcount }>\text { t-table }=4.01>1.99 \text { ), LSQ model is effective } \\
\text { in increasing the curiosity. Curiosity through the four main skills found, } \\
\text { namely: questioning skills, reinforcement, explanation skills, and classroom } \\
\text { management. The average result of the competency percentage on LSQ } \\
\text { learning is } 72 \% \text { (medium category). LSQ is strongly recommended to be } \\
\text { applied by prospective elementary school teachers. }\end{array}$ \\
\hline
\end{tabular}

\section{PENDAHULUAN}

Keterampilan pedagogik menjadi syarat utama calon guru. Penguasaan konsep menjadi keharusan sebelum mengajarkan materi kepada siswa. Keterampilan pedagogik perlu dilatih dan dikembangkan melalui strategi khusus (Niswati danSayekti 2020).

Salah satu yang dilakukan untuk meningkatkan keterampilan pedagogik yaitu kegiatan microteaching. Microteaching sebagai sarana berlatih untuk mengembangkan keterampilan berbicara, keterampilan menjelaskan, dan manajemen kelas perlu difasilitasi model pembelajaran yang baik. Model pembelajaran yang baik yaitu model pembelajaran yang membuat peserta didik aktif.

Kompetensi profesional yang dibutuhkan guru SD yaitu kompetensi pedagogik, kepribadian, profesional dan kompetensi sosial (Sukirman 2012). Guru yang berkualitas adalah guru yang memiliki keempat kompetensi dimaksud. Lebih detailnya guru harus memiliki pengetahuan yang mendalam dan luas tentang materi yang menjadi bidang 
keilmuannya, memiliki pengetahuan yang baik tentang sifat dan karakter peserta didik, serta mengetahui tujuan pendidikan dan metode untuk mencapai kompetensi yang akan dicapai.

Komponen profesionalisme guru yang melibatkan bukan hanya pengetahuan melainkan keterampilan dalam mengelola kelas. Sebuah model yang mengidentifikasi kemampuan kognitif dan karakteristik afektif, motivasi sebagai dua komponen utama kompetensi profesional guru (Gambar 1).

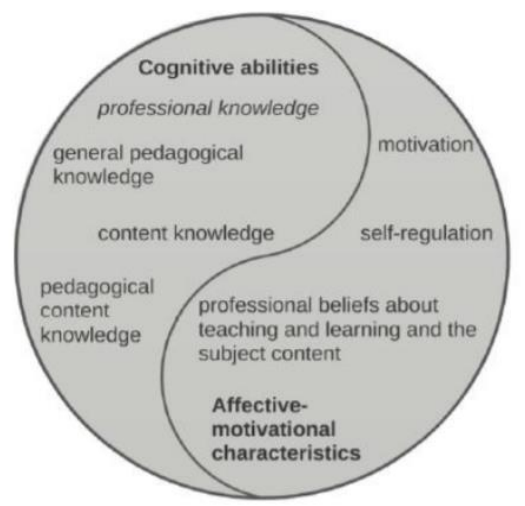

Gambar 1. Kompetensi Profesional Guru (Blomeke dan Delaney 2012)

Berdasarkan Gambar 1 menunjukan bahwa kualifikasi calon guru SD mempunyai tuntutan keterampilan sesuai abad 21. Selain pemahaman konsep sebagai kemampuan pedagogik guru diperlukan curiousity dalam menggalinya melalui pertanyaan pertanyaan sebelum mengembangkan keterampilan yang lain, sehingga sangat penting pemahaman konsep dan keterampilan mengajar ditingkatkan terlebih dahulu (Raharja et al 2018).

Penyusunan pembelajaran IPA melalui keterampilan proses sains dalam membuktikan konsep IPA sangat dibutuhkan di era abad 21 (Vani et al 2015). Kemampuan berpikir ilmiah melalui eksperimen dengan latihan sebagai seorang saintis melalui microteaching. Learning Start with a Question (LSQ) dianggap mampu memfasilitasi calon guru dalam kegiatan microteaching. Berdasarkan latar belakang di atas, penelitian ini bertujuan untuk (1) Mengungkap bagaimana penerapan model pembelajaran LSQ daalm kegiatan microteaching calon guru SD. (2) Menguji peningkatan rasa ingin tahu dan pemahaman konsep ilmiah calon guru SD.

\section{METODE}

Jenis penelitian quasi experimental melalui pembelajaran LSQ dalam kegiatan microteaching (Sugiyono 2013). Adapun kegiatan microteaching yang dilakukan dengan Tahap Pendahuluan (introduction) terdiri dari: (1) Membuka pelajaran dan (2) Melakukan pretes. Tahap Penyajian (presentation) terdiri dari: (1) Uraian (explanation) dan pemaparan, (2) Contoh (example) dan aplikasi (application) dan (3) Latihan (exercise). Selanjutnya Tahap Penutup meliputi: (1) Mengadakan postes (post-test), (2) Evaluasi dan balikan untuk meningkatkan performa calon guru SD.

Populasi penelitian adalah mahasiswa Program Studi Pendidikan Madrasah Ibtidaiyah, UNSIQ Jawa Tengah di Wonosobo. Teknik pengambilan sampel menggunakan purposive sampling yaitu sampel bertujuan untuk mengidentifikasi kompetensi calon Guru SD. Sampel penelitian sebanyak 31 mahasiswa. Metode pengumpulan data menggunakan 30 soal tes pemahaman konsep, angket dan observasi rasa ingin tahu calon guru. Kompetensi 
Gantina $^{1}$ \& Khoiri ${ }^{2}$ - Penerapan Model Pembelajaran Learning ...

yang ditingkatkan ada empat kompetensi yaitu: Keterampilan bertanya, penguatan, keterampilan menjelaskan dan manajemen kelas. Teknik analisis menggunakan uji t untuk mengetahui keefektifan model LSQ serta peningkatan rasa ingin tahu dan pemahaman konsep IPA calon Guru SD. Selanjutnya menggunakan uji gain untuk mengetahui peningkatan pemahaman konsep calon guru SD. Bagan alur penelitian dapat disajikan dalam Gambar 2.

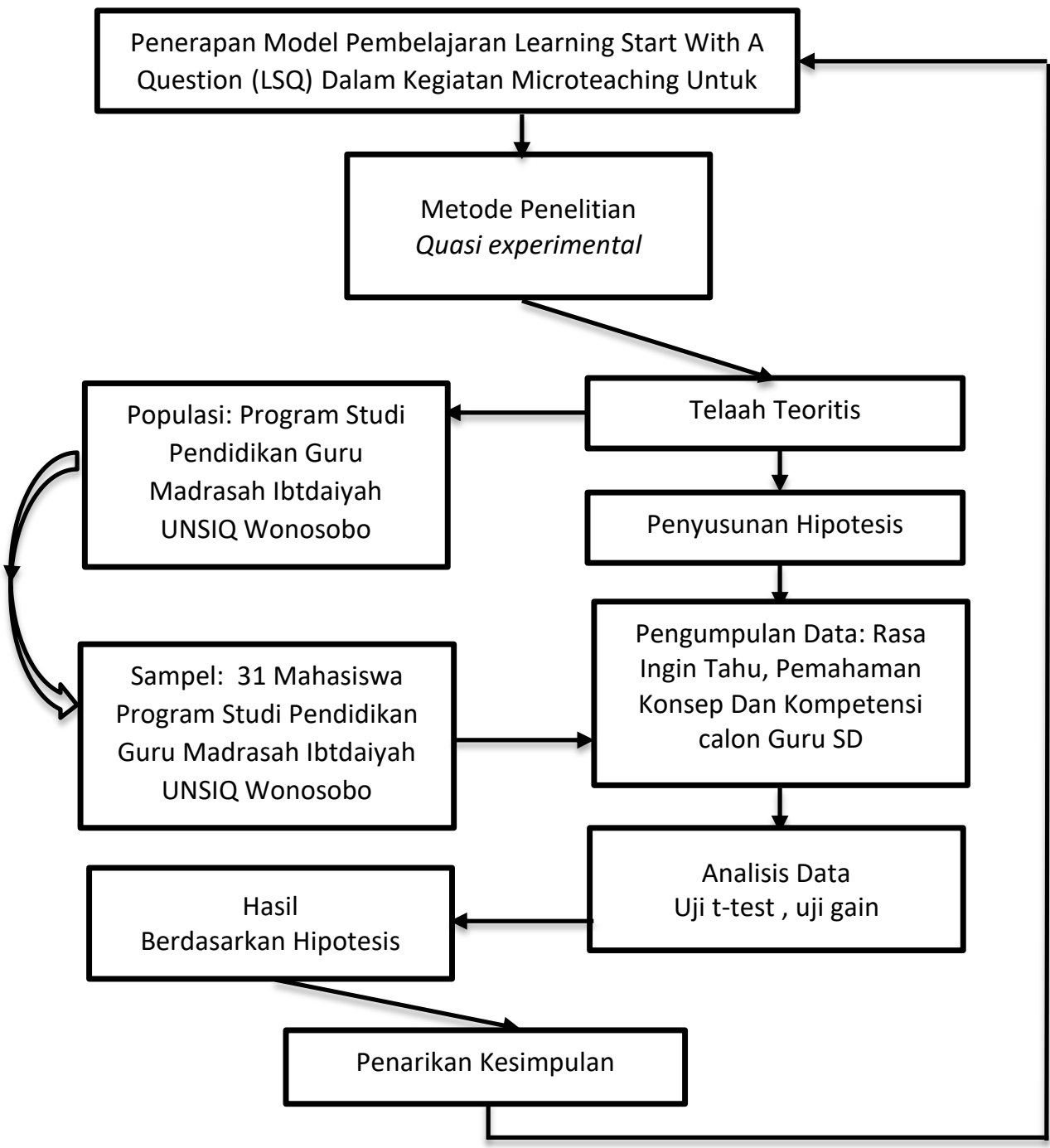

Gambar 2. Proses penelitian diadaptasi dari (Khoiri dan Sunarno 2019)

\section{HASIL DAN PEMBAHASAN}

Analisis pendahuluan uji normalitas pada nilai bahwa $L_{\text {hitung }}<L_{\text {tabel }}$ berarti data berdistribusi normal dan memenuhi syarat untuk dilakukan uji hipotesis, yang dikuatkan melalui uji $\mathrm{F}$ (Fisher) dengan hasil $\mathrm{F}_{\text {hitung }}<\mathrm{F}_{\text {tabel }}$ artinya data tersebut terbukti homogen. Berdasarkan analisis mengenai peningkatan pemahaman konsep IPA calon Guru SD digunakan perhitungan uji gain diperoleh perhitungan uji gain sebesar 0,3 yang berarti ada 
peningkatan pemahaman konsep IPA calon Guru SD kelas eksperimen dengan model pembelajaran LSQ berbasis eksperimen yang berkategori rendah.

Analisis perbedaan penerapan model pembelajaran LSQ terhadap pemahaman konsep calon Guru SD didapatkan hasil uji hipotesis t-test. Uji hipotesis t-test diperoleh $t_{\text {hitung }}$ adalah 4,01 sedangkan $t_{\text {tabel }}$ taraf kesalahan relatif $5 \%$ adalah 1,99 , karena $t_{\text {hitung }}>$ $t_{\text {tabel }}(4,01>1,99)$ maka $H_{0}$ ditolak dan $H_{1}$ diterima menunjukan ada keefektifan penerapan model pembelajaran LSQ untuk meningkatkan keterampilan Mengajar dan pemahaman konsep IPA calon Guru SD. Penelitian dikuatkan oleh (Suprijino 2015) bahwa belajar konsep dapat mengurangi beban memori dalam mengategorisasikan stimulus; sebagai unsur-unsur pembangun kemampuan berpikir, belajar konsep sebagai dasar proses mental yang lebih tinggi dan mengatasi masalah. Hal ini sesuai dengan pembelajaran model LSQ. Proses pembelajaran calon Guru SD dibimbing oleh guru dan lembar kerja terstruktur. Calon Guru SD dituntut lebih aktif untuk menemukan suatu konsep, inovasi dan kreasi dalam menerapkan model LSQ dengan tujuan untuk membangun keterampilan bertanya, penguatan, menjelaskan serta manajemen kelas. Berdasarkan implementasi model LSQ. Adapun indikator keterampilan mengajar yang diteliti dapat disajikan dalam Gambar 3 (Usman 2010).

Keterampilan Bertanya

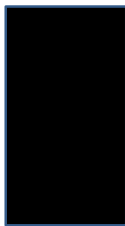

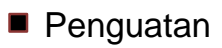

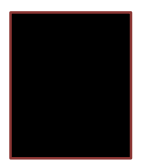

- Kemampuan menjelaskan

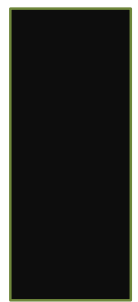

Manajemen Kelas

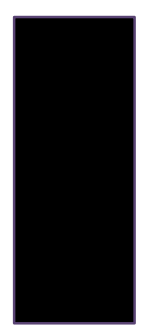

Gambar 3. Keterampilan Calon Guru SD

Berdasarkan Gambar 2 menunjukan model LSQ mampu menggali empat keterampilan dasar mengajar calon guru SD. Keterampilan penguatan mempunyai skor ternedah sebesar $65 \%$ dan tertinggi manajemendan kelas sebesar $76 \%$.

\section{Keterampilan Bertanya}

Pada kegiatan microteaching keterampilan bertanya calon guru SD sebesar $70 \%$ kategori sedang. Bertanya sebagai symbol calon guru dapat berpikir secara aktif, dimulai dengan pertanyaan akan timbul sebuah permasalahan dan bagaimana dalam mengatasi masalah. LSQ memberikan kesempatan calon guru untuk bertanya dengan kemampuan berpikir tingkat tinggi. Bertanya sebagai rumusan masalah yang akan di selesaikan. Oleh karena itu dalam setiap proses pembelajaran, model pembelajaran apapun yang digunakan bertanya merupakan kegiatan yang selalu merupakan bagian yang tidak terpisahkan (Akkaya dan Demirel 2012). Pertanya sering diajukan oleh siswa dengan pertanyaan yang sama, krena masih membingungkan. Keterampilan bertanya seorang guru fituntut untuk memberikan respon yang positif sehingga siswa akan terus mengeksplorasi kemampuan bertanya.(Isrokatun et al. 2019).

Pertanyaan telah lama digunakan sebagai alat pengajaran oleh guru dan pembimbing untuk menilai pengetahuan siswa, mendorong pemahaman, dan merangsang pemikiran 
Gantina $^{1}$ \& Khoiri ${ }^{2}$ - Penerapan Model Pembelajaran Learning ...

kritis. Model LSQ mengfasilitasi kemampuan bertanya yang sistematis. Pertanyaan yang dibuat dengan baik akan menghasilkan wawasan baru, menghasilkan diskusi, dan mendorong eksplorasi materi pelajaran yang komprehensif. Teknik pertanyaan akan menunjukan pengembangan keterampilan kritis dan kreatif siswa. Pertanyaan yang dibangun dengan buruk dapat menghambat pembelajaran dengan menciptakan kebingungan, mengintimidasi siswa, dan membatasi pemikiran kreatif (Etemadzadeh, Seifi, dan Far 2013). Guru paling sering mengajukan pertanyaan konvergen tingkat rendah yang mengandalkan ingatan faktual siswa tentang pengetahuan sebelumnya daripada mengajukan pertanyaan tingkat tinggi dan divergen yang mendorong pemikiran mendalam, yang mengharuskan siswa menganalisis dan mengevaluasi konsep yang dikaji dalam keterampilan berpikir tingkat tinggi merupakan bagian dari persiapan calon guru SD (Seman, Yusoff, dan Embong 2017).

Pertanyaan sering kali digunakan untuk merangsang mengingat kembali pengetahuan sebelumnya, meningkatkan pemahaman, dan membangun keterampilan berpikir kritis. Guru mengajukan pertanyaan untuk membantu siswa mengungkap apa yang telah dipelajari, untuk mengeksplorasi materi pelajaran secara komprehensif, dan untuk menghasilkan diskusi dan interaksi siswa. Memahami taksonomi pertanyaan dan praktik terbaik dapat membantu guru merumuskan pertanyaan yang lebih luas yang tidak hanya merangsang mengingat kembali pengetahuan faktual, konseptual, dan prosedural yang penting, tetapi juga mengharuskan peserta didik untuk menganalisis, mengevaluasi, dan menciptakan (Zulkifli dan Hashim 2019). Perhatian yang lebih besar pada metakognisi dan tanggapan pribadi pelajar melalui pertanyaan yang efektif dapat menuntun siswa pada wawasan yang dalam. Kejelasan, pengurutan, dan penyampaian pertanyaan, memengaruhi persepsi, motivasi, dan pencapaian hasil pendidikan yang diinginkan siswa. Pertanyaan adalah salah satu alat pengajaran yang paling kuat dan mengadopsi praktik terbaik dapat secara signifikan meningkatkan kualitas pengajaran (Chin dan Osborne 2008). Siswa melakukan pertanyaan mengindikasi telah berpikir secara ilmiah (Sari dan Hasibuan 2019).

\section{Penguatan}

Penguatan sebesar $65 \%$ calon guru SD menunjukan rendahnya kemampuan dalam memberikan respon positif kurang terbiasanya calon guru dalam memberikan penguatan dan pendalaman konsep sangat menghawatirkan (Leng dan Lim 2011). Penguatan yang dilakukan berupa evaluasi, pujian dan feedback dengan melatih saling menghargai pendapat, memberikan umpan balik. Tujuan penguatan untuk menekankan bahwa konsep yang dipelajari sangat penting, namun dalam penelitian ini calon guru SD belum terbiasa dalam memberikan penguatan, sehingga akan dimungkinkan jika tidak dilatih secara kontinyu akan menyebabkan miskonsepsi pada pemahaman siswa nantinya. Evaluasi yang dilaksanakan untuk meninjau kembali aktivitas serta hasil belajar apakah telah sesuai dengan konsep ilmiah, kesalahan kesalahan dalam praktik mengajar dengan memberikan saran dan perbaikan. Pujian berupa motivasi untuk berkembang dengan segala kemampuan yang dimiliki, mengeksplorasi dengan memberikan pujian atau reward. Tujuan diberikan pujian untuk memupuk percaya diri, motivasi, menghilangkan keraguan pada diri calon guru SD dengan penuh keyakinan.

Penguatan dalam pengajaran dapat diintegrasikan dalam nilai-nilai dalam lingkungan masyarakat dengan tujuan siswa mampu mengimplementasikan dalam kehidupan nyata. 
Siswa merasa apa yang dipelajari dapat bermakna (Muttaqin dan Raharjo 2018). Penguatan yang bersentuhan langsung dengan kehidupan akan lebih mudah dipahami.

Penguatan instruksional sangat penting dan menarik bagi guru karena memberikan petunjuk tentang alasan keberhasilan atau kegagalan akademis bagi siswa di sekolah. Dalam pengajaran, kesuksesan terjadi ketika perilaku yang diinginkan diperkuat secara memadai, Gagasan bahwa pembelajaran dapat dirangsang dan ditingkatkan melalui penggunaan penguat berasal dari praktik pendidikan. Kegiatan microteaching melatih kebiasan calon guru SD dalam memberikan penguatan yang baik. Bukan hanya berkutat pada penjelasan konsep saja, namun memberikan penguatan terhadap diri siswa bahwa kepentingan konsep bukan hanya sekedar ilmiah saja namun nilai-nilai yang terkandung dapat bermanfaat (Kinyanjui et al. 2015).

Penguatan memberikan stimulus iklim pelajaran, pengelolaan pelajaran yang proaktif, pelajaran yang terorganisir dengan baik dengan tujuan yang jelas, dukungan guru, lingkungan, pertanyaan berkualitas dan umpan balik adalah strategi penguatan kelas yang efektif. Kemampuan guru dalam menguatkan pembelajaran adalah kunci kesuksesan pembelajaran yang berkualitas.

\section{Keterampilan Menjelaskan}

Keterampilan menjelaskan $75 \%$ bagian yang tidak terpisahkan dari sebuah pengajaran yang efektif. Kemampuan menjelaskan akan menentukan pemahaman konsep yang diterima oleh siswa. Siswa SD tidak akan mampu untuk menemukan konsep secara mandiri tanpa adanya penjelasan terlebih dahulu dari guru. Peran guru sebagai fasilitator harus mampu menjelaskan dengan sistematis dan jelas. Penyampaian materi yang bermakna bagi kehidupan siswa akan lebih berkesan dalam membangun karakter, emosional, motivasi dan minat belajar siswa (Suganda, Sutrisno, dan Wardana 2017). Keterampilan menjelaskan dalam keberhasilan belajar melalui prinsip-prinsip dan tujuan belajar yang harus dikuasi oleh siswa (Pamuji 2019).

Keterampilan menjelaskan sangat berperan penting dalam transfer of knowledge kepada siswa. Siswa SD cenderung mendengarkan dan memperhatikan apa yang disampaikan oleh guru, ketika guru tidak bisa menjelaskan siswa tidak akan mudah memahami. Penjelasan materi dengan bahasa siswa akan lebih mudah diterima dibandingkan dengan bahasa yang ilmiah, artinya bahasa komunikatif dan sederhana akan lebih mudah dicerna oleh pemahaman siswa. Penjelasan bersifat sistematis untuk memberikan konsep dasar dan holistic. Keterampilan menjelaskan dengan penekanan penekanan konsep yang memberikan respon siswa dan memunculkan banyak pertanyaan serta rasa ingin tahu siswa yang tinggi (Kristiana et al. 2018).

\section{Manajemen Kelas}

Selanjutnya manajemen kelas sebesar $76 \%$ sebagai setting kelas yang asik dan menyenangkan sangat diperlukan. Kondisi kelas yang tidak kaku, tidak monoton akan membangkitkan motivasi belajar siswa lebih tinggi. Keadaan kelas yang aktif namun tidak gaduh sangat diidamkan oleh semua guru, budaya akademik yang bagus, adanya timbal balik dari guru dan siswa. Manajemen kelas akan menentukan dalam memanfaatkan alokasi waktu belajar. Alokasi waktu yang disusun secara sistematis dapat memberikan konsistensi belajar pada siswa. Penggunaan model, metode pembelajaran akan menentukan kondisi kelas (Oliver, Wehby, dan Nelson 2015). Model LSQ memberikan kondisi kelas yang berpartisipasi aktif dan inovatif. LSQ memberikan interkasi guru dan 
Gantina $^{1}$ \& Khoiri ${ }^{2}$ - Penerapan Model Pembelajaran Learning ...

siswa secara simultan, sehingga kualitas pembelajaran semakin baik. Manajemen kelas melalui kegiatan berkelompok kecil akan menumbuhkan kerjasama sosial, saling menghargai, saling memberikan saran dengan bertukar pengalaman. Kerjasama secara sebaya akan lebih menguntungkan satu sama lain. (Crispdi, Rickwood, Martin, dan Byrom 2020; Solfema dan Wahid 2018) pengembangan keterampilan dan pengalaman dalam fasilitasi kelompok, dan rasa kebersamaan serta memiliki yang lebih besar. Sementara tantangannya dalam membangun inisiatif, dukungan teman sebaya pada kerjasama kelompok.

\section{Kontribusi Model LSQ}

Berdasarkan Gambar 1 menunjukan keterampilan pedagogik calon guru SD memberikan penguatan paling rendah sebesar $65 \%$ dibandingkan keterampilan yang lain, pemberian penguatan konsep sangat relevan dengan pemahaman konsep yang dimiliki calon Guru SD, tidak akan memberikan penguatan yang baik jika konsep yang dipahami kurang meskipun baik cara menjelaskan. Pembelajaran LSQ memberikan kontribusi bahwa dengan berlatih memberikan pertanyaan untuk menggali konsep serta memberikan penguatan. Keterampilan memberikan penguatan dapat diindikasi melalui keingintahuan tinggi akan dapat menyelesaikan permasalahan belajar. Penyelesaian tugas belajar dapat teratasi, jika rasa ingin tahu siswa tinggi. Rasa ingin tahu memberikan kontribusi terhadap keterampilan keterampilan pedagogik lain. (Satria, Waluya, dan Siswanto 2018).

Rasa ingin tahu sebagai dorongan untuk melakukan sesuatu dimulai dengan bertanya, mengidentifikasi, membuktikan sampai saatnya menyimpulkan, kelemahan keterampilan mengajar belum dapat digali secara baik. Kebiasan kebiasaan budaya akademik, secara umum pemberian pelajaran masih dalam fase transfer of knowledge yang berdampak pada komunikasi pasif, dianggap semua siswa membutuhkan hal yang sama tanpa mempertimbangkan apa yang dibutuhkan siswa, memberi kesempatan siswa untuk menggali sumber belajar, mengidentifikasi konsep sehingga siswa paham sesuatu karena diberikan oleh guru semata. Hal ini sesuai dengan pembelajaran menggunakan model LSQ berbasis eksperimen berkontribusi terhadap peningkatan keterampilan mengjara meskipun belum maksimal, dari keempat keterampilan yang diteliti masih perlu ditingkatkan dengan inovasi metode lain.

Keterampilan dasar mengajar guru SD sebagian besar terdapat pada rasa percaya diri akan potensi yang dimilikinya, sehingga kurang dieksplorasi dan digali yang terjadi guru kurang kreatif dan inovatif. Penelitian tentang analisis kritis pendidikan sains bahwa guru belum mampu memberikan kesempatan siswa untuk mengeksplorasi keterampilan kinerja ilmiah melalui pembelajaran yang kontekstual. (Khoiri 2020; Nurlaili 2018). Calon guru harus mampu mempersiapkan segala sesuatunya terkait keterampilan dasar mengajar, calon guru harus banyak wawasan dan pengalaman agar keterampilan dasar mengajar semakin baik (Achdiani dan Rusliyani 2017), sehingga kegiatan microteaching berjalan dengan efektif, efisien dan professional (Nurwahidah 2020) karena microteaching memberikan pengalaman praktik mengajar kepada calon guru SD sebelum menjadi guru yang sesungguhnya (Mansyur 2017). Penerapan belajar mengajar melalui proses pelatihan atau peer teaching akan meningkatkan hasil belajar siswa (Mansur 2017; Sumiah, Aminuyati, dan Khosmas 2013).

Kompetensi professional seorang guru dapat dilakukan melalui kegiatan pelatihan mengajar melalui model LSQ terdapat penemuan 4 keterampilan dasar mengajar oleh calon guru SD. Dari keempat keterampilan yang dikuasai tentunya belum cukup ketika 
akan menjadi guru yang sangat professional, namun paling tidak sebagai modal dasar seorang guru dengan memaksimalkan keempat keterampilan sangat baik. LSQ memberikan kesempatan calon guru untuk mengeksplorasi keterampilan bertanya melalui respon, penguatan terhadap konsep dan aplikasi dalam kehidupan yang bermakna. Selanjutnya keterampilan menjelaskan secara sistematis menggunakan bahasa yang komunikatif, sederhana serta dapat mudah dipahami oleh siswa, dan keterampilan dalam manajemen kelas melalui belajar kelompok, kerjasama dan interaksi sosial memberikan kontribusi nyata pada calon guru SD. LSQ mampu memberikan keterampilan dasar mengajar, meskipun ada beberapa keterampilan yang belum maksimal. Rekomendasi penelitian berupa peningkatan keterampilan mengajar yang tidak cukup empat saja, namun sangat kompleks dan penting digali secara kontinyu untuk menjadi guru professional.

\section{SIMPULAN}

Berdasarkan uji gain sebesar 0,3 yang berkategori adanya peningkatan pemahaman konsep calon Guru SD kategori rendah. Berdasarkan uji t sebesar 4,01 dan t table sebesar 1,99 , sehingga $t_{\text {hitung }}>t_{\text {tabel }}(4,01>1,99)$ menunjukan model LSQ efektif digunakan dalam peningkatan rasa ingin tahu calon guru SD melalui empat keterampilan pokok yaitu: keterampilan bertanya, penguatan, keterampilan menjelaskan serta manajemen kelas. Hasil persentase rata rata keterampilan calon Guru SD terhadap pembelajaran LSO sebesar $72 \%$ kategori sedang. Rekomendasi penelitian untuk mempertimbangkan dalam memilih metode yang efektif sebelum melakukan pembelajaran. Implikasi penelitian bahwa model inovasi seperti LSQ sangat perlu diterapkan dalam pembelajaran IPA khususnya dalam meningkatkan kompetensi dasar calon guru SD. Keterbatasan penelitian pada kompetensi yang ditingkatkan hanya 4 kompetensi calon guru SD, padahal terdapat banyak kompetensi lain yang perlu dimilikinya.

\section{DAFTAR PUSTAKA}

Achdiani, Yani, and Ayu Rusliyani. (2017). "Pengetahuan Keterampilan Dasar Mengajar Dalam Menyiapkan Guru Sekolah Menengah Kejuruan." Teknobuga 5(2):34-43.

Akkaya, Nevin, and M. Volkan Demirel. (2012). "Teacher Candidates' Use of Questioning Skills in During-Reading and Post-Reading Strategies." Procedia - Social and Behavioral Sciences 46:4301-5.

Blömeke, S., \& Delaney, S. (2012). Assessment of teacher knowledge across countries: a review of the state of research. ZDM, 44(3), 223-247.

Chin, Christine, and Jonathan Osborne. (2008). "Students' Questions: A Potential Resource for Teaching and Learning Science." Studies in Science Education 44(1):1-39.

Crisp, D. A., Rickwood, D., Martin, B., \& Byrom, N. (2020). “Implementing a Peer Support Program for Improving University Student Wellbeing: The Experience of Program Facilitators." Australian Journal of Education 64(2):113-126.

Etemadzadeh, Atika, Samira Seifi, and Hamid Roohbakhsh Far. (2013). "The Role of Questioning Technique in Developing Thinking Skills: The Ongoing Effect on Writing Skill." Procedia - Social and Behavioral Sciences 70:1024-31.

Isrokatun, I., A. A. Syahid, H. E. Putri, J. Julia, and C. Sunaengsih. (2019). "Problem Posing Skill of Elementary School Students." Journal of Physics: Conference Series 1318(1).

Khoiri, Ahmad. (2020). "Analisis Kritis Pendidikan Sains Di Indonesia: (Problematika, Solusi Dan Model Keterpaduan Sains Dasar)." SPEKTRA: Jurnal Kajian Pendidikan Sains 6(1):19. 
Gantina $^{1}$ \& Khoiri ${ }^{2}$ - Penerapan Model Pembelajaran Learning ...

Khoiri, Ahmad, and Widha Sunarno. (2019). "How Is Students' Creative Thinking Skills ? An Ethnoscience Learning Implementation." Jurnal IImiah Pendidikan FisikaAl-BiRuNi 08(October):153-63.

Kinyanjui, Mary Wangari, Peter J. O. Aloka, Sabina K. Mutisya, Florentina Ndunge Ndeke, and Naphtal Michira Nyang'ara. (2015). "Classroom Reinforcement Schedules and Their Effectiveness in Selected Kenyan Primary Schools." Journal of Educational and Social Research (September).

Kristiana, Dini, Dan A. Muhibbin Magister, Administrasi Pendidikan, and Sekolah Pascasarjana. (2018). "Keterampilan Dasar Mengajar Dalam Pembelajaranmatematika Di Smp." Jurnal Managemen Pendidikan 13(2):204-9.

Leng, Jinsong, and Chee Peng Lim. (2011). "Reinforcement Learning of Competitive and Cooperative Skills in Soccer Agents." Applied Soft Computing Journal 11(1):1353-62.

Mansur, Nurdin. (2017). "Penerapan Keterampilan Mengajar Dalam Upaya Pencapaian Hasil Belajar Mahasiswa." Lantanida Journal 4(2):118.

Mansyur. (2017). "Keterampilan Dasar Mengajar Dan Penguasaan Kompetensi Guru (Suatu Proses Pembelajaran Micro)." El-Ghiroh XII(1):130-46.

Muttaqin, Muhamad Fauzan, and Tri Joko Raharjo. (2018). "The Implementation Main Values of Character Education Reinforcement in Elementary School." Journal of Primary Education 7(1):103-12.

Niswati, Fadilah Ismiya, and Ika Candra Sayekti. (2020). "Analisis Kompetensi Pedagogik Calon Guru Sekolah Dasar Dalam Mata Kuliah Microteaching." Profesi Pendidikan Dasar 1(1):1-14.

Nurlaili, Nurlaili. (2018). “Analisis Keterampilan Dasar Mengajar Guru Dalam Perspektif Guru Pamong Pada Mahasiswa Prodi PGMI Fakultas Ilmu Tarbiyah Dan Keguruan UIN Raden Fatah Palembang." JIP: Jurnal IImiah PGMI 4(1):28-40.

Nurwahidah, Indri. (2020). "Kemampuan Keterampilan Dasar Mengajar Mahasiswa Calon Guru Ipa Program Studi Pendidian Ipa." EduTeach : Jurnal Edukasi Dan Teknologi Pembelajaran 1(2):22-33.

Oliver, Regina M., Joseph H. Wehby, and J. Ron Nelson. (2015). "Helping Teachers Maintain Classroom Management Practices Using a Self-Monitoring Checklist." Teaching and Teacher Education 51:113-20.

Pamuji. (2019). “Peningkatan Kemampuan Menjelaskan Materi Pkn Tentang Asean Melalui Model Pembelajaran Mind Mapping Pada Siswa Kelas VI SDN Ringinkembar 03." JURNAL PENA SD 03(01):88-98.

Raharja, Steven, et. al. (2018). "Mengukur Rasa Ingin Tahu Siswa.” Journal Of Language, Literature, Culture, And Education POLYGLOT Vol. 14 No.2.

Sari, Nurhaty Purnama, and Wilda Fasim Hasibuan. (2019). "Teacher's Questioning Skills and Students' Responses in Science Subject Based on Parenting Style Perspectives." Jurnal Pendidikan Biologi Indonesia 5(1):85-92.

Satria, Oki Anggit, Budi Waluya, and B. Siswanto. (2018). “Model Discovery Learning Bernuansa Hypnoteaching Untuk Meningkatkan Kemampuan Mathematical Reasoning Dan Rasa Ingin Tahu Siswa." PRISMA, Prosiding Seminar Nasional Matematika 1:669-76.

Seman, Shamilati Che, Wan Mazwati Wan Yusoff, and Rahimah Embong. (2017). "Teachers Challenges in Teaching and Learning for Higher Order Thinking Skills (HOTS) in Primary School." International Journal of Asian Social Science 7(7):534-45.

Solfema, Solfema, and Syafrudin Wahid. (2018). "Peer Group Learning Method to Improve the College Student's Achievement." Journal of Nonformal Education 4(2):187-96.

Suganda, Rizky, Endro Sutrisno, and Irawan Wisnu Wardana. (2017). "Upaya Peningkatan Kemampuan Siswa Dalam Menjelaskan Perkembangan Teknologi Komunikasi Dan Transportasi Melalui Penerapan Metode Kooperatif Jigsaw." Jurnal Cakrawala 
Pendas 53(9):44-52.

Sugiyono. (2013). Metode Peneltian Kualitatif Dan R \& D. Bandung: Alfabeta.

Sukirman, Dadang. (2012). Pembelajaran Micro Teaching. Direktorat Jenderal Pendidikan Islam Kementerian Agama.

Sumiah, N., Aminuyati, and F. Y. Khosmas. (2013). “Analisis Keterampilan Mengajar Guru Dalam Meningkatkan Hasil Belajar Pada Mata Pelajaran Ekonimi Di SMA." Jurnal Pendidikan Dan Pembelajaran 2(9):1-17.

Suprijino, Agus. (2015). Cooperative Learning. Yogyakarta: Pustaka Pelajar.

Usman, M. Uze. (2010). Menjadi Guru Profesional. Bandung: PT Remaja Rosdakarya.

Vani, Siti, Et. al. (2015). “Pengaruh Model Learning Start With A Question Berbasis Eksperimen Sederhana Terhadap Pemahaman Konsep Fisika Kelas X Man 2 Model Palu." Jurnal Pendidikan Fisika Tadulako (JPFT). Vol. 5. No. 2.

Zulkifli, Hafizhah, and Rosnani Hashim. (2019). "The Development of Questioning Skills through \&lt;I\&gt;Hikmah\&lt;/I\&gt; (Wisdom) Pedagogy." Creative Education 10(12):2593-2605. 